\title{
Working
}

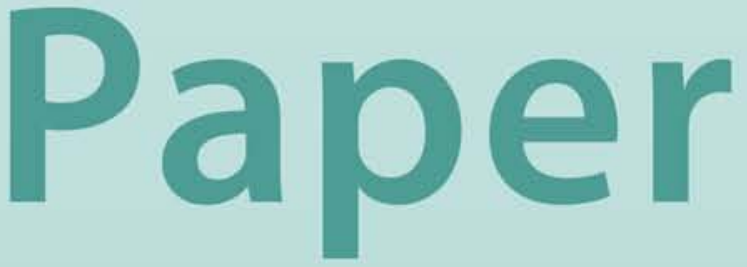


Economic and Environmental Benefits of Eliminating Log Export Bans--The Case of Costa Rica

Nalin Kishor, Muthukumara Mani, and

Luis Constantino 


\title{
IMF Working Paper
}

Fiscal Affairs Department

\section{Economic and Environmental Benefits of Eliminating Log Export Bans-The Case of Costa Rica}

\author{
Prepared by Nalin Kishor, Muthukumara Mani, and Luis Constantino ${ }^{1}$
}

Authorized for distribution by Howell H. Zee

October 2001

\begin{abstract}
The views expressed in this Working Paper are those of the author(s) and do not necessarily represent those of the IMF or IMF policy. Working Papers describe research in progress by the author(s) and are published to elicit comments and to further debate.
\end{abstract}

An increasing number of tropical timber producing nations have enacted bans on export of logs. Proponents argue that a log export ban is a second-best policy tool for addressing environmental externalities; it also creates more jobs and improves scale efficiencies domestically. Theoretical arguments, however, suggest that log export bans are largely incapable of achieving their objectives. However, little quantitative evidence exists. The authors maintain that eliminating log export bans in Costa Rica could generate economic gains as high as \$14 million annually in addition to the environmental benefits.

JEL Classification Numbers: F13, F18, and Q23

Keywords: trade and environment, forestry, log export ban (LEB), sustainable management, Latin America, Costa Rica

Author's E-Mail Addresses: nkishor@worldbank.org, mmani@1mf.org, lconstantino@worldbank.org

\footnotetext{
${ }^{1} \mathrm{Mr}$. Mani is with the Fiscal Affairs Department of IMF. Mr. Kishor and Mr. Constantino are with the World Bank. The authors would like to thank Mr. Michael Keen and Ms. Ana Lucía Coronel for their very useful comments and suggestions on an earlier draft of this paper.
} 
Contents

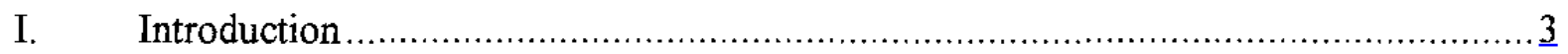

II. The Importance of Forests in Costa Rica ..............................................

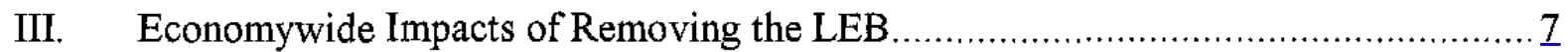

A. Economywide Net Surplus as a Result of Removing the LEB ................... 9

B. Estimating the Environmental (Non-timber) Costs and Benefits ................ 10

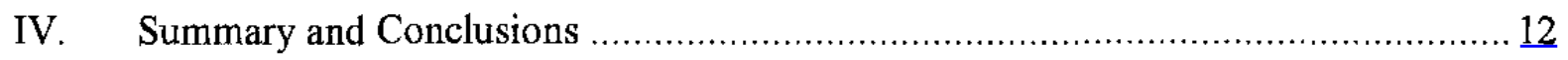

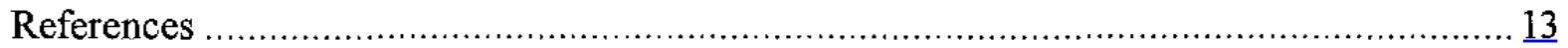

Tables

1. Annual Welfare Changes from Removal of the LEB .................................. 10

2. Annual Economic and Environmental Costs and Benefits to Removing a LEB ........ 11

Figure

1. Gains from Removing the Log Export Ban in Costa Rica .................................. $\underline{8}$ 


\section{INTRODUCTION}

Global warming, and other transnational environmental problems like ozone depletion, deforestation, and desertification, has highlighted the concern for the fate of the earth's environment. These issues have come to play an important role in the formulation of national and global policies on the environment. While improvement in environment has become a serious concern of policy makers in many countries, positions of countries vary both with respect to their vulnerability and their willingness to pay to avoid environmental degradation. Because of the difficulties associated with attaining the international cooperation that will be needed for effective policies to protect the global environment, there is concern that countries might start using unilateral measures to address global environmental concerns. In the search for policies that would achieve this goal, much attention has been given to links between trade and the environment especially the use of trade measures to address environmental concerns. $^{2}$

One of the major focuses of this debate has been on tropical timber trade. In the recent debates on trade and environment, there is a recurrent view that trade in forest resources harms the environment. It is thus argued that the tropical timber trade, in particular, causes deforestation and therefore that trade is responsible for environment degradation. ${ }^{3} \mathrm{~A}$ substantial and possibly increasing number of tropical timber producing nations have enacted bans or similar provisions constraining the export of logs. A case has been made for an export ban on logs, as a second-best policy tool for addressing environmental externalities: it is claimed that deforestation will decrease because of the reduction in timber exports. In addition, job creation, capturing more value-added domestically, and improving the scale efficiency of domestic processing are also often given as reasons for such restrictions. Many developing countries thus look to timber trade restrictions as a means of achieving economic, environmental, and social objectives.

Several justifications are offered why a timber export tax and, its most extreme form-a log export ban (LEB) should be implemented. Industrial processing of natural resources has long been considered a possible development strategy for primary product exporting countries. ${ }^{4}$ Timber export taxes, and other restrictive trade policies have often been pursued to encourage forest-based industrialization and, to 'compensate' domestic processors for discrimination faced in developed country markets. It is believed that, by adding export-oriented downstream processing industries, countries that are currently exporting

\footnotetext{
${ }^{2}$ Recent calls for broadening the objectives of WTO to further the use of trade interventions for environmental policies will, if successful, open the door to a whole host of unilateral trade measures.

${ }^{3}$ Deforestation is known to lead to soil erosion, siltation, loss of water resources and biodiversity in addition to contributing to global warming.

${ }^{4}$ General issues relating to resource-based industrialization have been widely discussed in the literature (Roemer (1979), Wall (1979, 1980), Yeats (1981) and Alam (1983) among others). Processing issues related to minerals and petroleum have been discussed in Radetzki (1977) and Auty (1990).
} 
primary products could increase value added domestically, and consequently, their export earnings. The creation of jobs as a result is expected to give a boost to the economy. More recently, much of the focus of LEBs have been on the fact that these policies will reduce harvesting pressure on the forests by increasing value added per log extracted.

The theoretical conclusions of the literature on international trade belie the above arguments. In general, trade restrictions (such as taxes, quotas, and bans) are likely to be welfare reducing and myriad benefits (for example, increased efficiency of resource use, reduction in unproductive rent-seeking activities, etc., Thomas and Nash 1991) are expected to accrue to trade liberalization. Trade restrictions can be welfare enhancing only in special circumstances. For example, in the case of a country that has market power in the export commodity, an optimal export tax can be used to raise welfare (Bhagwati 1971; Devarajan and others 1996; Wisemann and Sedjo 1981). However, in most small open economies that are price-takers, imposing export restrictions is poor policy, harmful not only to exports but overall growth and welfare.

Furthermore, if the specific policy objective is to promote a downstream processing industry (protection of an infant industry), an indirect subsidy through trade restrictions is not the first-best instrument. By implicitly subsidizing the processing industry a country may end up encouraging the expansion of an inefficient downstream sector that is wasteful of the primary input because of its artificially low relative price. A direct subsidy (say, to address a credit market failure) is preferable since it would avoid any production distortions arising from input price distortions (Bhagwati and Ramaswami 1963; Diamond and Mirrlees 1971). In overall terms, because trade restrictions are likely to be distortionary and can result in large welfare losses, there is no a priori justification for claiming that the effect of an export ban will be favorable for the conservation of the primary resource, let alone in enhancing overall economic welfare.

The trade and the environment literature suggests that the use of trade restrictions as a surrogate environmental policy is not an efficient instrument in cases of production-related environmental problem because they fail to influence the method of production. Baumol and Oates (1988) argue that an internationally optimal tax on the externality is required and there is no set of tariffs/export taxes capable of sustaining the Pareto optimum which would be yielded by the optimal tax. However, Baumol and Oates conclude that in the absence of a truly Pigouvian tax on production, trade restrictions can be used, but only in a second best setting to maximize the welfare of the importing/exporting country or to move the global economy towards a "quasi optimum."

The theoretical results specifically of a LEB invariably suggest a tradeoff between achieving the environmentally sustainable level of harvesting, and improving national welfare. They imply that more rapidly the environmental damage grows with log output, the more likely the ban is to raise welfare. At the same time, the more elastic the demand for logs as inputs (into processed goods), the less likely a ban is to both raise welfare relative to free trade and more 
likely it is to lead to overharvesting (Dean 1992). ${ }^{5}$ In addition the results also confirm that a small open economy exporting a good whose production incurs environmental damage could actually gain from removal of its export restrictions if it is also ensured that the appropriate domestic policy to correct the environmental problem was in place (Anderson 1992).

In consonance with theory, empirical experience has not been encouraging in terms of the impact of LEBs on forest conservation. Tropical timber export taxes and bans have proved only moderately successful in achieving the desired results in South East Asia. For example, although expanded processing capacity was established in Malaysia, Philippines and Indonesia, it was achieved at high economic costs, both in terms of the direct costs of subsidization as well as the additional costs of wasteful and inefficient processing operations ( See, for example, Barbier (1992); Barbier et al., (1992); Gillis (1990); Vincent and Binkley (1991); Vincent (1992)). In a more recent paper, Boscolo and Vincent (2000) argue that often in the absence of any regulation, loggers can be expected to ignore the negative environmental impacts of logging, as they derive little or no financial gain from mitigating them. They further add that even in the presence of regulations that induce compliance with minimum diameter cutting limits, loggers are often tempted to reenter the forests prematurely (sooner than the prescribed cutting cycle) to log the commercial-sized timber left standing.

In addition as a long-term forest-based industrialization strategy, ensuring export sales of processed products through denying processors in other countries access to logs has proven difficult to sustain (Barbier et al., 1992). By depressing domestic timber prices below their pre-ban level, LEBs have often discouraged adoption of sustainable practices in timber harvesting and have reduced incentives to adopt modern technology geared toward increasing wood recovery ratios in timber processing. ${ }^{6}$ Lower stumpage values also imply lower appropriable rents to the government, thereby hurting domestic tax collections (Repetto and Gillis, 1988). Finally, lower log prices have reduced relative returns to forestry, and at the margin have intensified the pressure to clear forested land for competing agricultural crops and plantations.

In sum, there are good theoretical arguments, supported by empirical evidence, that LEBs are largely incapable of achieving the objectives expected of them. Yet there is still a strong view in many developing countries that LEBs are the panacea to both their economic and environmental problems, and they have been implemented in country after country.

\footnotetext{
${ }^{5}$ This is based on the ratio between annual increments and annual harvests, i.e., when the ratio is greater than one it shows that these resources have not been over-utilized, when it is less than one the resources have been over-utilized.

${ }^{6}$ This also runs counter to the Porter hypothesis which states that environmental regulation can, in fact, lead to improved competitiveness: efficient regulations may actually stimulate innovation, efficiency gains, industrial growth, and competitiveness (Porter, 1991).
} 
This may be so because so far very little quantitative evidence exists on the economic and environmental effects of a timber trade liberalization i.e., in terms of the removal of export restriction or lifting of a logging ban. Towards that end, this paper seeks to fulfill the gap in the literature with two main objectives. The first is to illustrate the overall efficiency gains arising from repealing the LEB in Costa Rica. The second associated objective is to estimate the magnitude of environmental costs and benefits and to compare them with the pure efficiency gains. The environmental benefits include both global benefits such as carbon sequestration and biodiversity conservation and local benefits such as water and soil conservation. Two alternatives of coping with the increased demand that would result from the removal of LEB are considered: sustainably managed old-growth forests and new plantation forests.

Our main findings are as follows:

- Production gains: Removing the LEB results in significant productive efficiency gains. Under a plausible scenario efficiency gains can be as high as $\$ 14$ million per annum or about 0.1 percent of GDP.

- $\quad$ Environmental benefits and costs: Environmental gains are at best only a small fraction of the overall efficiency gains. If the increased demand for timber were to be met from new plantation forests, the economy would experience environmental benefits. These, however, account for less than 5 percent of the efficiency gains. On the other hand, if demand comes from old growth forests, then even under sustainable management there will be some environmental costs, but they are again a small fraction of efficiency gains to the economy.

Based on these results, the paper recommends that removing the LEB and developing plantation forests will enable Costa Rica to achieve efficiency gains at the same time sustain the environment.

\section{THE IMPORTANCE OF FORESTS IN COSTA RICA}

Costa Rica boasts a rich and diverse ecological landscape, as well as a wealth of natural resources. It has a total land area of about 5.2 million hectares with a variety of ecosystems and is home to over half a million different species (mostly micro-organisms and insects), and about 6 percent of the entire earth's bio-diversity. A large expanse of Costa Rica's environment is protected by the National System of Conservation. Despite this measure, Costa Rica suffers from severe threats of loss to its bio-diversity. Of the plant species, almost 1,500 are threatened with extinction as a consequence of timber exploitation and other forms of deforestation. Most of the country's problem with deforestation, and associated problems of soil erosion, are a result of the excessive clearing of land for logging and to some extent cattle ranching. Primary natural forests have shrunk from more than 4.5 million hectares at the turn of the century to less than 1.3 million hectares today (World Bank 2000). The current rate of deforestation is estimated at about 16,000 hectares per year and most of this leads to 
transformation of forests to pastures and farmland. Less than 400,000 hectares of this remaining forest lie outside of strictly protected areas and is available for production activities.

Forest production in Costa Rica currently accounts for less than 3 percent of total agricultural output and only 1 percent of gross domestic product. In 1995-96 the industry's exports amounted to about $\$ 50$ million and had overhauled the export earnings from livestock long considered as the most important agricultural export. The annual revenues from forest taxes are estimated to be between US $\$ 8-10$ million. ${ }^{7}$ This forms 0.4 to 0.5 percent of total annual revenue collections. ${ }^{8}$ At the same time it is claimed that only a fraction of Costa Rica's forest potential is being exploited and the sector offers the promise of greater export earnings, employment, and government revenues in the future if managed properly (World Bank 2000). By removing the LEB, and assuming that the log prices rise by 67 percent and the tax rate on logs remains unchanged, it is estimated that tax revenues will increase from US $\$ 10$ million to US $\$ 17$ million, i.e., by about 70 percent .

Over and above these direct economic benefits, environmental services from forests make an important contribution as well. For some forest types, carbon sequestration, and benefits related to water conservation, biodiversity protection, and existence and option values are estimated to be as much as 50-60 percent of the total economic value of the forest (Kishor and Constantino 1994; Castro and others 1998). ${ }^{9}$ Hence, forest management needs to pay adequate attention to the protection of these services in addition to timber extraction.

\section{ECONOMYWIDE IMPACTS OF REMOVING THE LEB}

In an attempt to protect its forests and to encourage further development of a domestic timber processing industry, Costa Rica imposed a LEB on May 7, 1986. Law 7575, passed in 1996, extended the ban for an unspecified period of time. The ban has isolated the domestic market from the international one. The most immediate effect of isolating the domestic market from the international was a substantial drop in the domestic prices of logs. It has been estimated that the domestic prices for some varieties of logs could be as low as 30 percent of the international market price (Stewart 1992).

\footnotetext{
${ }^{7}$ This is a basic stumpage tax of 10 percent of stumpage value. We do not have information for tax revenues from processed products which would much increase revenue gencrated from forestry sector.

${ }^{8}$ In 2000 total central government revenue collection was US\$1,996.8 million, and nominal GDP was US\$15,885 million.

${ }^{9}$ The total economic valuc of the forest consists of revenues from timber, nontimber forest products, ecotourism, and the estimated monetization of environmental services such as those for carbon sequestration, biodiversity protection, protection of water, and option and existence values.
} 
Clearly, the most important result of removing the LEB would be to once more integrate the Costa Rican timber market with the world market. Since Costa Rica is a price-taker in the international market for logs, domestic wood prices will rise to the level of world prices. Figure 1 conceptualizes the effects of the removal of the LEB on the forestry sector for the owners of resources as well as the downstream processors. ${ }^{10}$ The corresponding changes in producer/consumer surpluses can be quantified for the various agents in the economy. The gains and losses are then aggregated to see if the policy change is desirable as measured by whether it creates a net decrease or increase in the overall surplus. ${ }^{11}$

\section{Figure 1. Gains From Removing the Log Export Ban in Costa Rica}

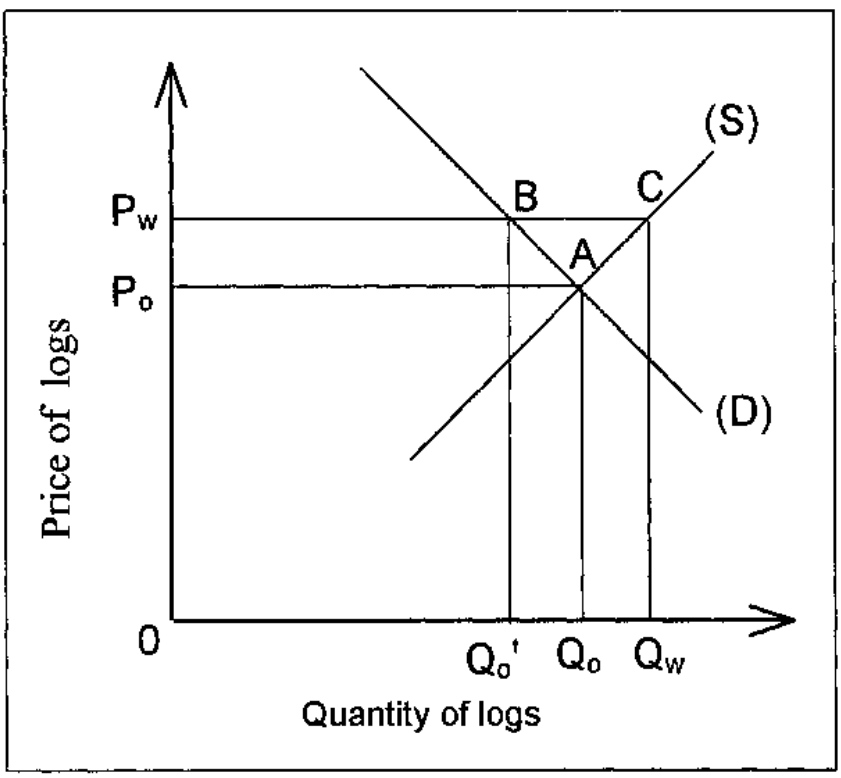

In Figure 1, the initial domestic demand by downstream processors for rough logs is given by $\mathrm{Q}_{\mathrm{O}}$ and the average price is $\mathrm{P}_{\mathrm{O}} \cdot{ }^{12}$ The long-run demand and supply curves for the "industry," are represented by $\mathrm{D}$ and $\mathrm{S}$. Removal of the LEB leads to a rise in prices to the world level, $\mathrm{P}_{\mathrm{W}}$. Total $\log$ harvests go up to $\mathrm{Q}_{\mathrm{W}}$, while consumption in the domestic market falls to $\mathrm{Q}_{0}$ '. Resource (log) owners gain area $\mathrm{AP}_{\mathrm{O}} \mathrm{P}_{\mathrm{W}} \mathrm{C}$, whereas processors of logs lose area $\mathrm{AP}_{\mathrm{O}} \mathrm{P}_{\mathrm{W}} \mathrm{B}$

\footnotetext{
${ }^{10}$ It is being assumed that there is an integrated processing sector which takes the sawnlogs and converts them into final products.

${ }^{11}$ For a succinct and non-technical discussion of the logic of considering only consumer surplus to evaluate the merits of overall policy changes, see Bishop 1987.

${ }^{12}$ This is the weighted average of the market stumpage values of the species traded in Costs Rica. The weights used are the volumes of the various species traded. In this analysis it is assumed that the change in the mix of species being harvested is small and does not require changing the weighing pattern.
} 
due to a rise in the prices of their inputs. ${ }^{13}$ The net gain in surplus to Costa Rica attributable to removing the LEB is given by the area of the triangle $\mathrm{ABC}{ }^{14}$

\section{A. Economywide Net Surplus as a Result of Removing the LEB}

In addition to the elasticity of the demand and supply curves, the area of triangle ABC will also depend on the extent of the initial difference between the domestic and international prices. A sector study for Costa Rica suggests that if the country is integrated into the world timber market, domestic log prices will likely increase by 67 percent of the existing price of $\$ 85.30$ per cubic meter of logs; and could rise by as much as 135 percent for some timber species (Stewart 1992). Table 1 reports the loss of surplus to processors, the gain of surplus to $\log$ owners, and the net surplus accruing to the economy for different parameter combinations. $^{15}$ The net surplus ranges from $\$ 6.4$ million to $\$ 52.7$ million per year. The redistribution of surplus from log processors to log owners ranges from $\$ 36$ million to $\$ 71$ million.

It is clear from Table 1 that the net increase in welfare (due to a 67 percent increase in domestic wood prices) as a result of removing the LEB, ranges from $\$ 6.4$ to $\$ 23.6$ million per year. Clearly, based on this estimate, removing the LEB is a welfare improving policy change for Costa Rica. ${ }^{16}$

\footnotetext{
${ }^{13}$ In the short run this increased surplus arises from the additional surplus accruing to the currently logged area, and from the surplus accruing to the expansion of the extensive margin of logging. In the long run, a potential substitution of area under pasture and farming to plantation forestry also contributes to an increase in the consumer surplus.

${ }^{14}$ This is the static efficiency gain, as measured by the famous "Harberger triangles." The environmental impacts will be estimated separately.

${ }^{15}$ There are no elasticity estimates specifically for Costa Rica. Plausible values have been taken from published studies for other countries (Binkley 1987, Binkley and Dykstra 1987, Constantino 1988, Percy and Constantino 1989, Uutela 1987, and Vincent 1989).

${ }^{16}$ There are other avenues of revenue generation for the government from lifting the log export ban which are not explicitly shown here. A major cost associated with a log export ban is the foregone fiscal revenue. A large part of the resource rent is in the form of logging/stumpage fee that could actually be captured back by government by lifting the ban.
} 
Table 1: Annual Welfare Changes from Removal of the LEB (\$ million)

\begin{tabular}{lcccc}
\hline $\begin{array}{l}\text { Demand } \\
\text { elasticity }\end{array}$ & $\begin{array}{c}\text { Supply } \\
\text { elasticity }\end{array}$ & $\begin{array}{c}\text { Percent price } \\
\text { increase }\end{array}$ & $\begin{array}{c}\text { Area ABC } \\
\text { (net increase } \\
\text { in welfare) }\end{array}$ & $\begin{array}{c}\text { Area } \mathrm{P}_{0} \mathrm{P}_{\mathrm{w}} \mathrm{BA} \\
\text { (redistributive } \\
\text { component) }\end{array}$ \\
\hline-0.25 & 0.1 & 67 & 6.4 & 49.8 \\
-1.00 & 0.3 & 67 & 23.6 & 36.1 \\
-0.25 & 0.1 & 100 & 14.2 & 68.9 \\
-1.0 & 0.3 & 100 & 52.7 & 38.5 \\
\hline
\end{tabular}

\section{B. Estimating the Environmental (Non-timber) Costs and Benefits}

The previous section attempted to quantify the potential welfare changes as they manifest themselves in the market. Environmental services, on the other hand, do not typically have markets, but since removing the LEB will also impact the environment, these costs and benefits should be quantified. There are several environmental services associated with forested land, such as carbon sequestration, soil and water related benefits, biodiversity conservation, etc. In this section, we take account of all these externalities as they accrue to a typical hectare of forested land in Costa Rica.

It is first assumed that the increased timber supply is forthcoming from (additional) forested area with sustainable management techniques. Then, under some plausible assumptions regarding per hectare environmental costs, and an elasticity of log supply of 0.1 , the total environmental costs due to increased harvesting are calculated at $\$ 2.2$ million and $\$ 3.3$ million for the two price increase scenarios depicted in Table 2. ${ }^{17}$

If the increase in supply comes about through conversion of land from annual crops and cattle ranching to plantation forestry (as a response to the increase in profitability of the latter) then there will be associated benefits of about $\$ 75$ per hectare, primarily due to the carbon sequestration function of plantations. ${ }^{18}$ With a supply elasticity of 0.1 , and assuming

${ }^{17}$ With elasticity of supply at 0.1, a 67 percent price rise would increase log harvests by 6.7 percent. At the current harvest level of 950,000 cubic meters, this works out to 63,650 cubic meters $(950,000 \times 0.067)$. Under sustainably managed forestry, about 2 cubic meters of wood can be harvested per hectare per year. Thus, 31,825 hectares have to be put under managed forestry to provide this increase. As compared to virgin forest, net carbon loss under managed forestry is about $\$ 60$ per year per hectare. There are other losses (biodiversity, reduced hydrological buffering, etc.) which amount to about $\$ 10$ per hectare per year. Hence the total loss is about $\$ 2.2$ million in this case.

${ }^{18}$ For plantation forests there is an average annual carbon sequestration of about 5 tons per hectare. Logging operations, on the other hand, cause a release of about 1.7 tons of carbon per hectare per year. Valuing carbon at about $\$ 25$ per ton gives a net sequestered value of $\$ 75$ per hectare per year. As explained in footnote 13 , with an elasticity of supply of 0.1 , annual harvests would increase by 63,650 cubic meters. About 12.5 cubic meters of 
that the entire increase comes from plantations, these benefits range from $\$ 380,000$ to $\$ 780,000$ per annum. If the supply price elasticity is assumed to be 0.3 , the benefits range from $\$ 1.2$ million to $\$ 1.7$ million.

Table 2: Annual Economic and Environmental Costs and Benefits to Removing a LEB (\$ million)

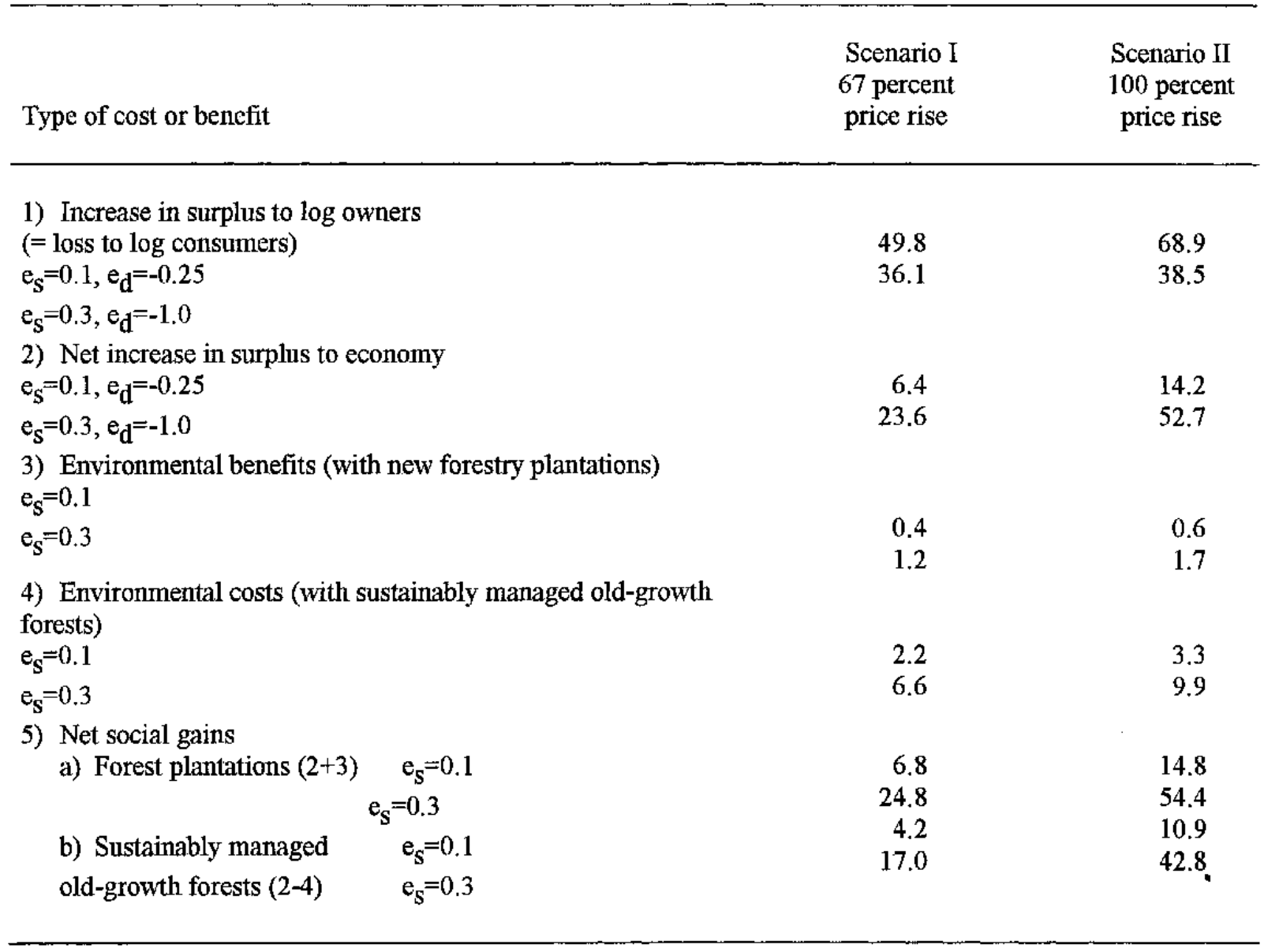

As shown in part $5 \mathrm{a}$ of Table 2, if the additional wood harvests originate in plantations environmental benefits will add to the economy's net increase in economic welfare. But even if the additional harvests come from sustainably managed old-growth forests, there is a clear case for the removal of the LEB since the increase in economic welfare, due to efficiency gains, is significantly larger than the monetized value of the environmental losses. For 
example, a price rise of 67 percent results in a US\$6.4 million efficiency gain and a US $\$ 2.2$ million environmental cost (with the net economic gain of $\$ 4.2$ million per year).

Table 2 also makes clear that environmental benefits are, at best, a small fraction of the benefits accruing due to efficiency gains. The environmental cost of achieving the increased supply through (sustainable) exploitation of old-growth forests is higher (US\$6.6 million), but still not very large when contrasted with plausible efficiency gains of \$23.6 million in Scenario I.

\section{SUMMARY AND CONCLUSIONS}

Our findings suggest that Costa Rica could achieve significant welfare gains as a result of reducing trade restrictions via removal of the LEB. Under a plausible scenario efficiency gains can be more than US\$14 million per annum, forming about 0.1 percent of its GDP. At the same time, government revenues from timber taxation will increase by US\$ 7 million per annum.

If the increased timber demand, resulting from the removal of the LEB is met from old-growth forests, the additional forest area required is about 47,500 hectares. This is less than 4 percent of the area under natural forest cover; less than 10 percent of the area currently under commercial exploitation; and equal to 2.5 times the area deforested annually! The environmental costs related to increased forest exploitation under sustainable management are about 23 percent of the efficiency gains, but become smaller if the supply elasticity of the resource is higher.

If the increased demand for timber, resulting from the removal of the LEB were to be met from developing new plantation forests, there would be environmental benefits arising from carbon sequestration and water and biodiversity conservation. ${ }^{19}$ These benefits are small however, being less than 5 percent of the efficiency gains due to trade liberalization.

Our analysis indicates that removing the log export ban will be a welfare enhancing policy reform for Costa Rica. The increased demand for logs may be directed to old-growth forests. However, if adequate regulations for sustainable management can be implemented, this is not likely to cause excessive pressures for deforestation.

On the other hand, if the increased demand can be met from the development of new forest plantations the country will tend to gain environmental benefits. Thus, a policy reform package of removing the log export ban, and simultaneous development of forest plantations is likely to lead to "win-win" outcomes where the country gains both in terms of the efficiency of resource use and in terms of environmental sustainability.

\footnotetext{
${ }^{19}$ Including both local benefits to Costa Rica as well as global benefits to rest of the world.
} 


\section{References}

Alam, M. Shahid, 1983, "Efficiency Differentials Favoring Resource-Based Industries," Journal of Development Economics, Vol. 13 (December 1983), pp. 361-366.

Auty, Richard M., 1990, "Resource-Based Industrialization: Sowing the Oil in Eight Developing Countries" (Oxford: Clarendon Press).

Barbier, E., 1992, "Economic Aspects of Tropical Deforestation in South East Asia," paper prepared for the workshop on "The Political Economy of South East Asia's Forests," Center for South East Asian Studies, School of Oriental and African Studies, London.

Barbier, E., J. Burgess, B. Aylward, and J. Bishop, 1992, "Timber Trade, Trade Policies and Environmental Degradation," London Environmental Economic Center Working Paper DP92-01 (London: International Institute for Environment and Development).

Baumol, Willian J., and W.E. Oates, 1988, "The Theory of Environmental Policy" (New York: Cambridge University Press, $2^{\text {nd }}$ ed.), pp. 266-78.

Bhagwati, Jagdish, 1971, "The Generalized Theory of Distortions and Welfare," in Trade, Balance of Payments, and Growth: Papers in International Economics in Honor of Charles P. Kindleberger, Chapter 12.

and V.K. Ramaswami, 1963, "Domestic Distortions, Tariffs, and the Theory of Optimum Subsidy," Journal of Political Economy, Vol. 71 (February), pp. 44-50.

Binkley, C.S., 1987, "Economic Models of Timber Supply," in The Global Forest Sector: An Analytical Perspective, ed. by Markku Kallio, Dennis Dykstra, and Clark Binkley (New York: John Wiley and Sons). and D.P. Dykstra, 1987, "Timber Supply," in The Global Forest Sector: An Analytical Perspective, ed. by Markku Kallio, Dennis Dykstra, and Clark Binkley (New York: John Wiley and Sons).

Bishop, Richard C., 1987, "Economic Values Defined," in Valuing Wildlife: Economic and Social Perspectives, ed. by Daniel Decker and Gary R. Goff (Boulder: Westview Press).

Boscolo, Marco, and Jeffrey R. Vincent, 2000, "Promoting Better Logging Practices in Tropical Forests: A Simulation Analysis of Alternative Regulations," LAND ECONOMICS (U.S.); Vol.76, No. 1, pp. 1-14.

Castro R., F. Tattenbach, N. Olson, and Luis Gamez, 1998, "The Costa Rican Experience with Market Instruments to Mitigate Climate Change and Conserve Biodiversity" (April) MINAE, FUNDECOR and the World Bank. 
Constantino, Luis F., 1988, "Analysis of the International and Domestic Demand for Indonesian Wood Products," Project INS/83/019, Report for the Food and Agricultural Organization of the United Nations, Department of Rural Economy, University of Alberta.

Devarajan, Shantayanan, Delfin Go, Maurice Schiff, and Sethaput Suthiawart-Narueput, 1996, "The Whys and Why Nots of Export Taxation," Policy Research Working Paper No.1684 (Washington: World Bank).

Diamond, Peter, and J.A. Mirrlees, 1971, "Optimal Taxation and Public Production, Part I: Production Efficiency," Vol. 61 (1), pp. 8-27.

1971, "Optimal Taxation and Public Production, Part II: Tax Rules," American Economic Review, Vol. 61 (3), pp. 261-78.

Gillis, M., 1990, "Forest Incentive Policies," prepared as background paper for the World Bank Forest Policy Paper.

Kishor, Nalin M., and Luis Constantino, 1994, "Sustainable Forestry: Can it Compete?" Finance \& Development, Vol. 31(4), pp. 36-9.

Krueger, Anne O., 1974, "The Political Economy of the Rent-Seeking Society," American Economic Review, (June).

Margolick Michael, and Russell Uhler, 1986, "The Economic Impact of Removing Log Export Restrictions in British Columbia," Information Report 86-2 (April), Forestry Economics and Policy Analysis Project, University of British Columbia.

Percy, M.B., and Luis F. Constantino, 1989, "The Softwood Lumber Dispute and Its Impact on the Economy of British Columbia: A General Equilibrium Analysis," Forest Economics and Policy Analysis Research Unit, Working Paper 125, University of British Columbia.

Porter,Michael, 1991, “Americas Green Strategy," Scientific American (April), p. 168.

Radetzki, Marian, 1977, "Where Should Developing Countries' Minerals be Processed? The Country View Versus the Multinational View," World Development, Vol. 5, No. 4 (April), pp. 325-34.

Repetto, Robert, and Malcolm Gillis, eds., 1988, Public Policies and the Misuse of Forest Resources (New York: Cambridge University Press).

Roemer, Michael, 1979, "Resource-Based Industrialization in the Developing Countries," Journal of Development Economics, Vol. 6, No. 2 (June), pp. 45-74. 
Sharma, Narendra P., ed., 1992, "Managing the World's Forests: Looking for Balance Between Conservation and Development," (Dubuque, Iowa: Kendall/Hunt Publishing Company).

Stewart, Rigoberto, 1992, "An Economic Study of Costa Rica's Forestry Sector," background paper for the Costa Rica Forest Sector Review, (Washington: World Bank).

Thomas, Vinod, and John Nash, 1991, "Reform of Trade Policy: Recent Evidence From Theory and Practice," World Bank Research Observer, Vol. 6, pp. 219-40.

Uutela, E., 1987, "Demand for Paper and Board: Estimation of Parameters for Global Models," in The Global Forest Sector: An Analytical Perspective, ed. by Markku Kallio, Dennis Dykstra, and Clark Binkley (New York: John Wiley and Sons).

Vincent, Jeffrey R., 1989, "Optimal Tariffs on Intermediate and Final Goods: The Case of Tropical Forest Products," Forest Science, Vol., 35 (3) pp. 720-31.

and C.S. Binkley, 1991, "Forest Based Industrialization: A Dynamic Perspective," Development Discussion Paper No. 389 (Cambridge, Massachusetts: Harvard Institute for International Development (HIID)).

, 1992, "The Tropical Timber Trade and Sustainable Development," Science, Vol. 256 (June) pp. 1651-55.

Wall, David, 1979, "Industrial Processing of Natural Resources," World Bank Commodity Working Paper No. 4 (Washington: World Bank).

J. Cody, and H. Hughes, 1980, "Policies For Industrial Progress in Developing Countries" (New York : Published for the World Bank by Oxford University Press).

Wisemann, A. Clark, and Roger Sedjo, 1981, "Effects of an Export Embargo on Related Goods: Logs and Lumber," American Journal of Agricultural Economics (August) pp. 423-29.

World Bank, 1993, "Costa Rica Forestry Sector Review," World Bank Report No.11516-CR. Agricultural Operations Division, Country Department II, LAC Regional Office, (Washington).

World Bank, 2000, "Costa Rica: Forest Strategy and the Evolution of Land Use," Evaluation Country Case Study Series, Operations Evaluation Department (Washington).

Yeats, Alexander J., 1981, "Trade And Development Policies: Leading Issues for the 1980s" (New York : St. Martin's Press). 